\title{
Data report: microbial abundance in subseafloor sediments of the equatorial Pacific Ocean, Expedition 320/321 ${ }^{1}$
}

\author{
Jens Kallmeyer ${ }^{2}$
}

\begin{abstract}
Chapter contents

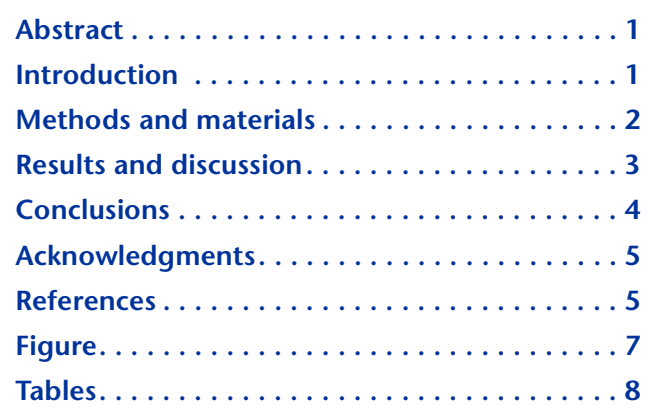

${ }^{1}$ Kallmeyer, J., 2013. Data report: microbial abundance in subseafloor sediments of the equatorial Pacific Ocean, Expedition 320/321. In Pälike, H., Lyle, M., Nishi, H., Raffi, I., Gamage, K., Klaus, A., and the Expedition 320/321 Scientists, Proc. IODP, 320/321: Tokyo (Integrated Ocean Drilling Program Management International, Inc.). doi:10.2204/iodp.proc.320321.214.2013 ${ }^{2}$ Helmholtz Centre Potsdam, GFZ German Research Centre for Geosciences, Section 4.5, Geomicrobiology, Telegrafenberg, 14473 Potsdam, Germany. kallm@gfz-potsdam.de

\begin{abstract}
Microbial cell abundances in sediment cores from Integrated Ocean Drilling Program Expedition 320/321 were quantified. Cell abundances varied between sites and with depth between $>10^{6}$ cells $/ \mathrm{cm}^{3}$ and $<10^{3}$ cells $/ \mathrm{cm}^{3}$. Even when using cell separation to increase sensitivity, cell abundances fall below the minimum detection limit in the deeper parts of several sites. At many of the sites, cell distribution does not follow the generally observed trend of a continuous decline with depth. Only some of these deviations appear to be correlated with lithologic changes.
\end{abstract}

\section{Introduction}

Since the first publications of subseafloor microbial abundances (Cragg et al., 1990, 1992; Parkes et al., 1994), cell abundance was generally assumed to decrease logarithmically by about three orders of magnitude with sediment depth over the upper 1000 meters below seafloor (mbsf). It was postulated that there is very little variability between sites (review in Parkes et al., 2000). Most of these studies were carried out on sediments from ocean margins and the eastern equatorial Pacific Ocean. Cell count data from Ocean Drilling Program (ODP) Leg 201 provided a first indication that subseafloor microbial cell abundance has at least some positive correlation with primary productivity of the overlying ocean (D'Hondt, Jørgensen, Miller, et al., 2003; D'Hondt et al., 2004). Drill sites in more oligotrophic oceanic regions (ODP Sites 1225 and 1226) revealed cell abundance profiles that had the same general trend but were shifted toward lower values, whereas sites from high-productivity areas (Sites 1229 and 1230) showed higher than average cell abundances.

Cell counts from the South Pacific Gyre (D'Hondt et al., 2009), the most oligotrophic oceanic region on Earth, provided further evidence for the observed positive correlation between productivity of the surface water and cell abundance; at the same subseafloor depth cell abundances were three to four orders of magnitude lower than any other previously published data set. Cell counts also showed a much stronger decrease with depth (approximately three orders of magnitude over the upper $1 \mathrm{mbsf}$ ). Despite the deviation in total cell abundance and rate of decrease with depth, the South Pacific Gyre data still show the same general trend, a logarithmic decrease with depth. Kallmeyer et al. (2012) 
used published data sets and their own cell count data to revise the estimate of global subseafloor microbial biomass (Whitman et al., 1998). Their study proposes not only much lower cell numbers but also an even lower biomass because of the assumption of smaller cell sizes. According to their study, cell numbers decrease with depth according to a power-law function and subseafloor microbial biomass is largely controlled by distance to shore and sedimentation rate.

Burial of photosynthetically derived organic matter from the photic zone is considered to be the primary source of electron donors for microbes in most sedimentary subseafloor environments (D'Hondt et al., 2004; Jørgensen, 2000). Studies that use very different approaches (e.g., quantification of intact phospholipids [Lipp et al., 2008] and pore water oxygen profiles [Røy et al., 2012]) indicate that organic matter availability strongly controls microbial activity and abundance. The rate of organic matter oxidation in subseafloor sediment has been described as declining with age according to a power-law function (Middelburg, 1989) or logarithmically (Rothman and Forney, 2007), similar to many cell count records.

Cell count data from several sites, however, do not follow the general trend of a smooth power-law decline with depth. Such deviations have multiple causes. Elevated temperature acting over geological time will lead to kinetically controlled abiotic organic maturation reactions converting recalcitrant organic matter such as kerogen into volatile products like fatty acids and petroleum that can migrate over long distances and supply microbial communities with organic substrates at cold sites like gas hydrates (Mangelsdorf et al., 2005) or cold seeps in the deep sea (Joye et al., 2004). Horsfield et al. (2006) showed that in areas with high heat flow, like the Nankai Trough off Japan, in situ microbes utilize thermogenically produced substrates because temperatures become sufficiently high at relatively shallow depths. Locations with an in situ coupling will most probably remain rare because despite reports about microbes being able to survive at temperatures well over $100^{\circ} \mathrm{C}$ (Blöchl et al., 1997; Kashefi and Lovley, 2003; Takai et al., 2008), at temperatures above $80^{\circ} \mathrm{C}$ microbial activity is severely reduced and sediment becomes basically pasteurized (Wilhelms et al., 2001). Given the relatively low temperatures in the sediment retrieved during Integrated Ocean Drilling Program (IODP) Expedition 320/321, thermogenic generation of microbial substrates can be ruled out.

Discrete layers of high organic matter content (e.g., sapropels) can also cause positive excursions in microbial abundance profiles (Cragg et al., 1999). Coolen et al. (2002) showed that Pleistocene sapro- pels in sediment of the Mediterranean Sea are still sites of enhanced microbial activity and abundance, despite their age and the low temperatures in the sediment. Apparent even at low temperatures, sufficient amounts of microbial substrates are produced from largely recalcitrant organic matter that was buried millions of years ago (Petsch et al., 2001).

Not just electron donors in the form of sedimentary organic carbon are controlling microbial abundance and activity in subseafloor sediments, but electron acceptors as well. In cases where deep-seated brines are present, electron acceptors like sulfate can diffuse upward and cause reverse geochemical gradients, leading to an increase in microbial activity ( $\mathrm{D}^{\prime} \mathrm{Hondt}$ et al., 2004) and abundance (Cragg et al., 1999).

The equatorial Pacific upwelling is a narrow band of high productivity within $2^{\circ}$ latitude of the Equator. The upwelling zone stretches from the west coast of the American continent westward for several thousand kilometers through the Pacific Ocean. High productivity in the surface water also leads to higher sedimentation rates and higher organic matter content in the deposited sediment. Sediment that was deposited inside the equatorial upwelling zone therefore have a different composition than those from outside the upwelling zone.

Throughout the Cenozoic, the northwestward movement of the Pacific plate has had a northward latitudinal component of $\sim 0.25^{\circ} \mathrm{Ma}$, transporting equatorial sediment gradually through the zone of highest sediment delivery. By moving the equatorial sediment out of the zone of high sedimentation, excessive burial beneath younger sediment is prevented. This phenomenon allowed Expedition 320/321, Pacific Equatorial Age Transect (PEAT), to recover a continuous Cenozoic record of the paleoequatorial Pacific.

Eight sites (U1331-U1338) were visited to obtain samples of sediment from the equatorial upwelling zone at a paleoposition of successive crustal ages on the Pacific plate.

\section{Methods and materials}

Samples were taken during Expedition 320/321 from March to July 2009. Because of the rather soft nature of the sediment, it was possible to use hydraulic piston coring for most cores. This technique is known to produce the least contaminated cores because the actual coring does not involve the use of drilling fluids (Kallmeyer, 2011; Smith et al., 2000). Samples from the center of a freshly cut core section are rarely contaminated, so despite the fact that these samples were drilled without contamination control, 
the obtained cell count profiles should be reasonably unaffected by contamination through infiltrating drilling fluid.

A cut-off sterile $3 \mathrm{~cm}^{3}$ plastic syringe was inserted into a freshly cut core section alongside the methane safety sample (Pälike, Lyle, Nishi, Raffi, Gamage, Klaus, and the Expedition 320/321 Scientists, 2010) and exactly $2 \mathrm{~cm}^{3}$ of sediment was extruded into a vial filled with $8 \mathrm{~mL}$ of $2.5 \% \mathrm{NaCl}$ solution with 2 vol\% formalin as a fixative. The vial was quickly closed and thoroughly shaken to form a homogeneous suspension. The sediment slurries were stored at $+4^{\circ} \mathrm{C}$ until analysis in Potsdam, Germany. Analysis was completed within about 7 months after the expedition. Experience has shown that formalin-fixed slurries maintain their original cell concentration for at least $1 \mathrm{y}$ as long as they are not diluted and kept cold. From each slurry, between two and four replicate filters were prepared and counted.

With the exception of samples from the upper few meters, cell concentrations were too low to be detected by direct counting, in which a small aliquot of slurry is put on a filter without any further treatment, stained with a DNA-specific stain (usually Acridine Orange or SYBR Green I), and counted manually. The minimum detection limit of this "classical" counting technique, which has been used on almost all ODP and IODP expeditions so far, is around $10^{5}$ cells $/ \mathrm{cm}^{3}$ (Kallmeyer, 2011). For deeper samples with lower cell abundances, a cell extraction that separates the cells from the mineral matrix is necessary. This technique can be used to lower the detection limit to levels of $\sim 10^{3}$ cells $/ \mathrm{cm}^{3}$. Although cell extraction does not recover $100 \%$ of the cells, values are usually within 1 standard deviation of the classical counting method (Kallmeyer et al., 2008, 2012a). Moreover, cell counts from extracts usually have a much smaller standard deviation than classical counts because of the higher number of cells counted.

All slurries were first checked for carbonate content by mixing a droplet of slurry with hydrochloric acid on a glass slide and looking for any mineral dissolution under a low-magnification microscope. Carbonates interfere with the cell extraction and drastically lower its efficiency. If carbonates were present, they were removed by dissolution through addition of a sodium acetate-acetic acid buffer containing 20 $\mathrm{mL} / \mathrm{L}(0.43 \mathrm{M})$ glacial acetic acid and $35 \mathrm{~g} / \mathrm{L}(0.43 \mathrm{M})$ sodium acetate. The carbonate dissolution mix has a high acidity but a moderate $\mathrm{pH}$ (4.6) in order to avoid any damage to the cells but to rapidly dissolve any carbonate minerals. Samples with high carbonate content were only treated with a carbonate dissolution step and filtered directly onto $0.22 \mu \mathrm{m}$ pore size polycarbonate filters, stained with SYBR Green I, and counted under a fluorescence microscope (Leica DM2500; Leica EL 6000 light source; BP 480/40 excitation filter; 505 dichromatic mirror; 527/30 suppression filter, $100 \times$ objective). Through dissolution of the carbonate minerals, the volume of slurry to be used for a single analysis can be increased by more than 1 order of magnitude. Samples with a higher percentage of noncarbonate minerals, usually clays and biogenic silica, were treated according to the cell extraction protocol of Kallmeyer et al. (2008), by which the cells are first detached from the mineral particles and then separated by density centrifugation.

Depth spacing of the cell count samples is between 3 and $10 \mathrm{~m}$. Although an exact stratigraphic correlation between the different holes is of utmost importance for high-resolution paleoceanographical work, the low resolution of the cell count data makes such efforts superfluous. Therefore, the uncorrected depth data were used.

Many of the cell counts were close to the minimum detection limit or even below. When dealing with such low values, a critical assessment of the background becomes an absolute necessity. Blank samples were processed alongside each sample processing run. On each sample and blank filter, 200 fields of view were counted. A sample was only considered a valid count if the total number of cells on 200 fields of view minus the average number of cells on the corresponding blank filters (i.e., the mean blank) was equal to or higher than three times the standard deviation of the mean blank (solid circles in Fig. F1). If the sample was lower than three times the standard deviation but still positive, the values were reported as below detection (open circles in Fig. F1). Some samples had negative cell counts after subtraction of the mean blank; those are reported as below detection (BD) in the tables or as open circles on the $y$-axes of Figure F1.

\section{Results and discussion}

The number of samples taken at each site varied considerably. Unfortunately, some vials broke during transport, causing gaps in the cell count profiles. At all depths, cell abundance varied between sites by about 2 orders of magnitude.

Contrary to most previously described cell count records from other locations that exhibit a logarithmic decline when plotted on a linear depth $/ \log _{10}$ cell count scale, many of the PEAT sites exhibit profiles that deviate strongly from this usual pattern. At least in part, these deviations appear to be related to lithologic and sedimentological changes, as described in 
the "Expedition 320/321 summary" chapter (Pälike et al., 2010). A summary of all cell count data is given in Figure F1.

\section{Site U1331}

The uppermost cell count sample is at 3 mbsf in a 7 $\mathrm{m}$ thick unit of Pleistocene-Pliocene clay and exhibits relatively low abundances $\left(2 \times 10^{4} \mathrm{cells} / \mathrm{cm}^{3}\right)$. The next sample at $8.2 \mathrm{mbsf}$ has a cell abundance that is more than 1 order of magnitude higher, reaching values of $3 \times 10^{5}$ cells $/ \mathrm{cm}^{3}$. This sample is in the lithologic unit that reaches to $26 \mathrm{mbsf}$ and consists of lower Oligocene to lower Eocene alternations of oozes with varying clay and calcium carbonate content. All cell count samples in this interval have cell abundances that are similar or higher than the uppermost sample.

A sharp lithologic change at 26 mbsf marks the Eocene-Oligocene transition, but cell abundances are not affected by this and remain at $\sim 2 \times 10^{4}$ cells $/ \mathrm{cm}^{3}$ throughout the rest of the core (Table T1).

\section{Site U1332}

At Site U1332, cell abundance close to the sedimentwater interface is $\sim 10^{5}$ cells $/ \mathrm{cm}^{3}$, similar to values of the subsurface peak at Site U1331. However, cell numbers decline more linearly with depth than at Site U1331 and reach the minimum detection limit of $\sim 10^{4}$ cells $/ \mathrm{cm}^{3}$ at $\sim 30 \mathrm{mbsf}$. Below this depth, no cells could be detected. When treating the cell counts that fall below detection as valid data, $\log _{10}$ cell abundance decreases linearly with depth. The depth at which cell counts start to fall below the detection limit roughly coincides with the change from lithologic Unit II to III, which is marked by a steep increase in $\mathrm{CaCO}_{3}$ content to $>80 \%$. Unfortunately, several samples from this depth interval were lost, making it impossible to constrain this observation to any greater detail (Table T2).

\section{Site U1334}

The cell count record at Site U1334 (Table T3) exhibits the strongest variation from the usual logarithmic decline with depth. Between 3 and 25 mbsf, cell numbers drop steadily with depth from $\sim 10^{5}$ to $10^{4}$ cells $/ \mathrm{cm}^{3}$. Below this depth, cell numbers alternate between $10^{4}$ and $10^{5}$ cells $/ \mathrm{cm}^{3}$ with local maxima at $\sim 60$ and $\sim 140$ mbsf and a minimum at $\sim 120$ mbsf. From the deepest local maximum at 140 mbsf downward, cell numbers decline more or less continuously to values of $\sim 5 \times 10^{3}$ cells $/ \mathrm{cm}^{3}$ at $200 \mathrm{mbsf}$.

Except for the local minimum in cell abundance at $\sim 40$ mbsf correlating with a minimum in $\mathrm{CaCO}_{3}$ content, the strong deviations from the normally expected decline of cell abundance with depth do not show any correlation with lithology, which mainly consists of nannofossil ooze and some clay in the upper 50 mbsf. The very pronounced greenish gray sediment color between $\sim 140$ and 190 mbsf does not show any correlation with cell abundance.

\section{Site U1335}

This site exhibits the most "normal" cell count record of all sites drilled during Expedition 320/321. Cell counts are $\sim 5 \times 10^{5}$ cells $/ \mathrm{cm}^{3}$ close to the sediment-water interface and drop with sediment depth according to a power-law function, reaching values of $\sim 10^{3}$ cells $/ \mathrm{cm}^{3}$ at $\sim 100 \mathrm{mbsf}$. Below $\sim 60 \mathrm{mbsf}$, single samples start to fall below the detection limit. A single replicate of the deepest sample (108.4 mbsf) shows a slight increase in cell abundance, but data are too scarce to make any interpretation. Both the change to continuously high carbonate content and the pronounced sediment color change from brown to greenish gray at 60 and $65 \mathrm{mbsf}$, respectively, have no influence on the cell count record (Table T4).

\section{Site U1337}

The most obvious feature of the cell count record at this site is the lack of a decrease over the upper 22.5 mbsf, with values of $2 \times 10^{5}$ cells $/ \mathrm{cm}^{3}$. Below this depth, cell counts decrease to $2 \times 10^{4}$ cells $/ \mathrm{cm}^{3}$ at 60 mbsf. Below this depth, $\log _{10}$ cell counts show only a very slight but almost linear decrease with depth, dropping by less than half an order of magnitude over $\sim 100 \mathrm{~m}$.

No change in lithology correlates with either change in the cell count profile at 22.5 and 60 mbsf (Table T5).

\section{Site U1338}

Despite some excursions between 30 and $80 \mathrm{mbsf}$, the cell count profile at Site U1338 follows the expected trend for marine sediment, starting at $10^{6}$ cells $/ \mathrm{cm}^{3}$ close to the sediment-water interface and dropping to $10^{4}$ cells $/ \mathrm{cm}^{3}$ at 150 mbsf (Table T6). The small-scale excursions cannot be related to any particular sedimentological or stratigraphic feature.

\section{Conclusions}

The cell count records of Expedition 320/321 deviate from the usual cell count records found in many other ODP and IODP drill sites. Some of these deviations can be related to lithologic changes caused by 
the varying productivity regimes in the overlying water. However, several changes cannot be related to lithology and may be caused by geochemical changes (e.g., redox fronts). A detailed investigation of geochemical and other controls on microbial abundance and distribution in subsurface sediment will remain the subject of future studies.

\section{Acknowledgments}

Samples and data were provided by the Integrated Ocean Drilling Program (IODP). I would like to thank the Expedition 320/321 Scientists for taking the samples. Heiko Pälike and Thomas Westerhold provided valuable insight into the stratigraphy and lithology of these sediments. Julia Nickel, Susann Kämpf, and Axel Kitte helped with the processing of the samples. This work was in part supported by the Schwerpunktprogramm ODP/IODP of the German Science Foundation (DFG).

\section{References}

Blöchl, E., Rachel, R., Burggraf, S., Hafenbradl, D., Jannasch, H.W., and Stetter, K.O., 1997. Pyrolobus fumarii, gen. and sp. nov., represents a novel group of archaea, extending the upper temperature limit for life to $113^{\circ} \mathrm{C}$. Extremophiles, 1(1):14-21. http:// www.ncbi.nlm.nih.gov/pubmed/9680332

Coolen, M.J.L., Cypionka, H., Sass, A.M., Sass, H., and Overmann, J., 2002. Ongoing modification of Mediterranean Pleistocene sapropels mediated by prokaryotes. Science, 296(5577):2407-2410. doi:10.1126/science. 1071893

Cragg, B.A., Harvey, S.M., Fry, J.C., Herbert, R.A., and Parkes, R.J., 1992. Bacterial biomass and activity in the deep sediment layers of the Japan Sea, Hole 798B. In Pisciotto, K.A., Ingle, J.C., Jr., von Breymann, M.T., Barron, J., et al., Proc. ODP, Sci. Results, 127/128 (Pt. 1): College Station, TX (Ocean Drilling Program), 761-776. doi:10.2973/odp.proc.sr.127128.184.1992

Cragg, B.A., Law, K.M., O'Sullivan, G.M., and Parkes, R.J., 1999. Bacterial profiles in deep sediments of the Alboran Sea, western Mediterranean, Sites 976-978. In Zahn, R., Comas, M.C., and Klaus, A. (Eds.), Proc. ODP, Sci. Results, 161: College Station, TX (Ocean Drilling Program), 433-438. doi:10.2973/ odp.proc.sr.161.267.1999

Cragg, B.A., Parkes, R.J., Fry, J.C., Herbert, R.A., Wimpenny, J.W.T., and Getliff, J.M., 1990. Bacterial biomass and activity profiles within deep sediment layers. In Suess, E., von Huene, R., et al., Proc. ODP, Sci. Results, 112: College Station, TX (Ocean Drilling Program), 607-619. doi:10.2973/odp.proc.sr.112.161.1990

D’Hondt, S., Jørgensen, B.B., Miller, D.J., Batzke, A., Blake, R., Cragg, B.A., Cypionka, H., Dickens, G.R., Ferdelman, T., Hinrichs, K.-U., Holm, N.G., Mitterer, R., Spivack, A., Wang, G., Bekins, B., Engelen, B., Ford, K., Gettemy, G.,
Rutherford, S.D., Sass, H., Skilbeck, C.G., Aiello, I.W., Guerin, G., House, C.H., Inagaki, F., Meister, P., Naehr, T., Niitsuma, S., Parkes, R.J., Schippers, A., Smith, D.C., Teske, A., Wiegel, J., Naranjo Padillo, C., and Solis Acosta, J.L., 2004. Distributions of microbial activities in deep subseafloor sediments. Science, 306(5705):22162221. doi:10.1126/science.1101155

D'Hondt, S., Spivack, A.J., Pockalny, R., Ferdelman, T.G., Fischer, J.P., Kallmeyer, J., Abrams, L.J., Smith, D.C., Graham, D., Hasiuk, F., Schrum, H., and Stancine, A.M., 2009. Subseafloor sedimentary life in the South Pacific Gyre. Proc. Natl. Acad. Sci. U. S. A., 106(28):1165111656. doi:10.1073/pnas.0811793106

D’Hondt, S.L., Jørgensen, B.B., Miller, D.J., et al., 2003. Proc. ODP, Init. Repts., 201: College Station, TX (Ocean Drilling Program). doi:10.2973/odp.proc.ir.201.2003

Horsfield, B., Schenk, H.J., Zink, K., Ondrak, R., Dieckmann, V., Kallmeyer, J., Mangelsdorf, K., di Primio, R., Wilkes, H., Parkes, R.J., Fry, J., and Cragg, B., 2006. Living microbial ecosystems within the active zone of catagenesis: implications for feeding the deep biosphere. Earth Planet. Sci. Lett., 246(1-2):55-69. doi:10.1016/ j.epsl.2006.03.040

Jørgensen, B.B., 2000. Bacteria and marine biogeochemistry. In Schulz, H.D., and Zabel, M. (Eds.), Marine Geochemistry: Berlin (Springer-Verlag), 173-207.

Joye, S.B., Boetius, A., Orcutt, B.N., Montoya, J.P., Schulz, H.N., Erickson, M.J., and Lugo, S.K., 2004. The anaerobic oxidation of methane and sulfate reduction in sediments from Gulf of Mexico cold seeps. Chem. Geol., 205(3-4):219-238. doi:10.1016/j.chemgeo.2003.12.019

Kallmeyer, J., 2011. Detection and quantification of microbial cells in subsurface sediments. Adv. Appl. Microbiol., 76:79-103. doi:10.1016/B978-0-12-387048-3.00003-9

Kallmeyer, J., Pockalny, R., Adhikari, R.R., Smith, D.C., and D'Hondt, S., 2012. Global distribution of microbial abundance and biomass in subseafloor sediment. Proc. Natl. Acad. Sci. U. S. A., 109(40):16213-16216. doi:10.1073/pnas.1203849109

Kallmeyer, J., Smith, D.C., Spivack, A.J., and D'Hondt, S., 2008. New cell extraction procedure applied to deep subsurface sediments. Limnol. Oceanogr.: Methods, 6:236-245. doi:10.4319/lom.2008.6.236

Kashefi, K., and Lovley, D.R., 2003. Extending the upper temperature limit for life. Science, 301(5635):934. doi:10.1126/science.1086823

Lipp, J.S., Morono, Y., Inagaki, F., and Hinrichs K.-U., 2008. Significant contribution of Archaea to extant biomass in marine subsurface sediments. Nature (London, U. K.), 454(7207):991-994. doi:10.1038/nature07174

Mangelsdorf, K., Haberer, R.M., Zink, K.-G., Dieckmann, V., Wilkes, H., and Horsfield, B., 2005. Molecular indicators for the occurrence of deep microbial communities at the JAPEX/JNOC/GSC et al. Mallik 5L-38 gas hydrate production research well. Bull. - Geol. Surv. Can., 585:111.

Middelburg, J.J., 1989. A simple rate model for organic matter decomposition in marine sediments. Geochim. 
Cosmochim. Acta, 53(7):1577-1581. doi:10.1016/ 0016-7037(89)90239-1

Pälike, H., Lyle, M., Nishi, H., Raffi, I., Gamage, K., Klaus, A., and the Expedition 320/321 Scientists, 2010. Proc. IODP, 320/321: Tokyo (Integrated Ocean Drilling Program Management International, Inc.). doi:10.2204/ iodp.proc.320321.2010

Pälike, H., Nishi, H., Lyle, M., Raffi, I., Gamage, K., Klaus, A., and the Expedition 320/321 Scientists, 2010. Expedition 320/321 summary. In Pälike, H., Lyle, M., Nishi, H., Raffi, I., Gamage, K., Klaus, A., and the Expedition 320/ 321 Scientists, Proc. IODP, 320/321: Tokyo (Integrated Ocean Drilling Program Management International, Inc.). doi:10.2204/iodp.proc.320321.101.2010

Parkes, R.J., Cragg, B.A., Bale, S.J., Getliff, J.M., Goodman, K., Rochelle, P.A., Fry, J.C., Weightman, A.J., and Harvey, S.M., 1994. Deep bacterial biosphere in Pacific Ocean sediments. Nature (London, U. K.), 371(6496):410-413. doi:10.1038/371410a0

Parkes, R.J., Cragg, B.A., and Wellsbury, P., 2000. Recent studies on bacterial populations and processes in subseafloor sediments: a review. Hydrogeol. J., 8(1):11-28. doi:10.1007/PL00010971

Petsch, S.T., Eglinton, T.I., and Edwards, K.J., 2001. ${ }^{14}$ Cdead living biomass: evidence for microbial assimilation of ancient organic carbon during shale weathering. Science, 292(5519):1127-1131. doi:10.1126/science. 1058332

Rothman, D.H., and Forney, D.C., 2007. Physical model for the decay and preservation of marine organic carbon. Science, 316(5829):1325-1328. doi:10.1126/science. 1138211
Røy, H., Kallmeyer, J., Adhikari, R.R., Pockalny, R., Jørgensen, B.B., and D'Hondt, S., 2012. Aerobic microbial respiration in 86-million-year-old deep-sea red clay. Science, 336(6083):922-925. doi:10.1126/science. 1219424

Smith, D.C., Spivack, A.J., Fisk, M.R., Haveman, S.A., Staudigel, H., and the Leg 185 Shipboard Scientific Party, 2000. Methods for quantifying potential microbial contamination during deep ocean coring. ODP Tech. Note, 28. doi:10.2973/odp.tn.28.2000

Takai, K., Nakamura, K., Toki, T., Tsunogai, U., Miyazaki, M., Miyazaki, J., Hirayama, H., Nakagawa, S., Nunoura, T., and Horikoshi, K., 2008. Cell proliferation at $122^{\circ} \mathrm{C}$ and isotopically heavy $\mathrm{CH}_{4}$ production by a hyperthermophilic methanogen under high-pressure cultivation. Proc. Natl. Acad. Sci. U. S. A., 105(31):10949-10954. doi:10.1073/pnas.0712334105

Whitman, W.B., Coleman, D.C., and Wiebe, W.J., 1998. Prokaryotes: the unseen majority. Proc. Natl. Acad. Sci. U. S. A., 95(12):6578-6583. doi:10.1073/ pnas.95.12.6578

Wilhelms, A., Larter, S.R., Head, I., Farrimond, P., di-Primio, R., and Zwach, C., 2001. Biodegradation of oil in uplifted basins prevented by deep-burial sterilization. Nature (London, U. K.), 411(6841):1034-1037. doi:10.1038/35082535

Initial receipt: 2 September 2012

Acceptance: 21 January 2013

Publication: 5 April 2013

MS 320321-214 
Figure F1. Cell abundance and distribution in drill cores retrieved during IODP Expedition 320/321. Solid circles mark cell counts above the minimum detection limit and open circles mark values below the minimum detection limit. Open circles directly on the $y$-axis indicate cell counts that were below the mean blank.
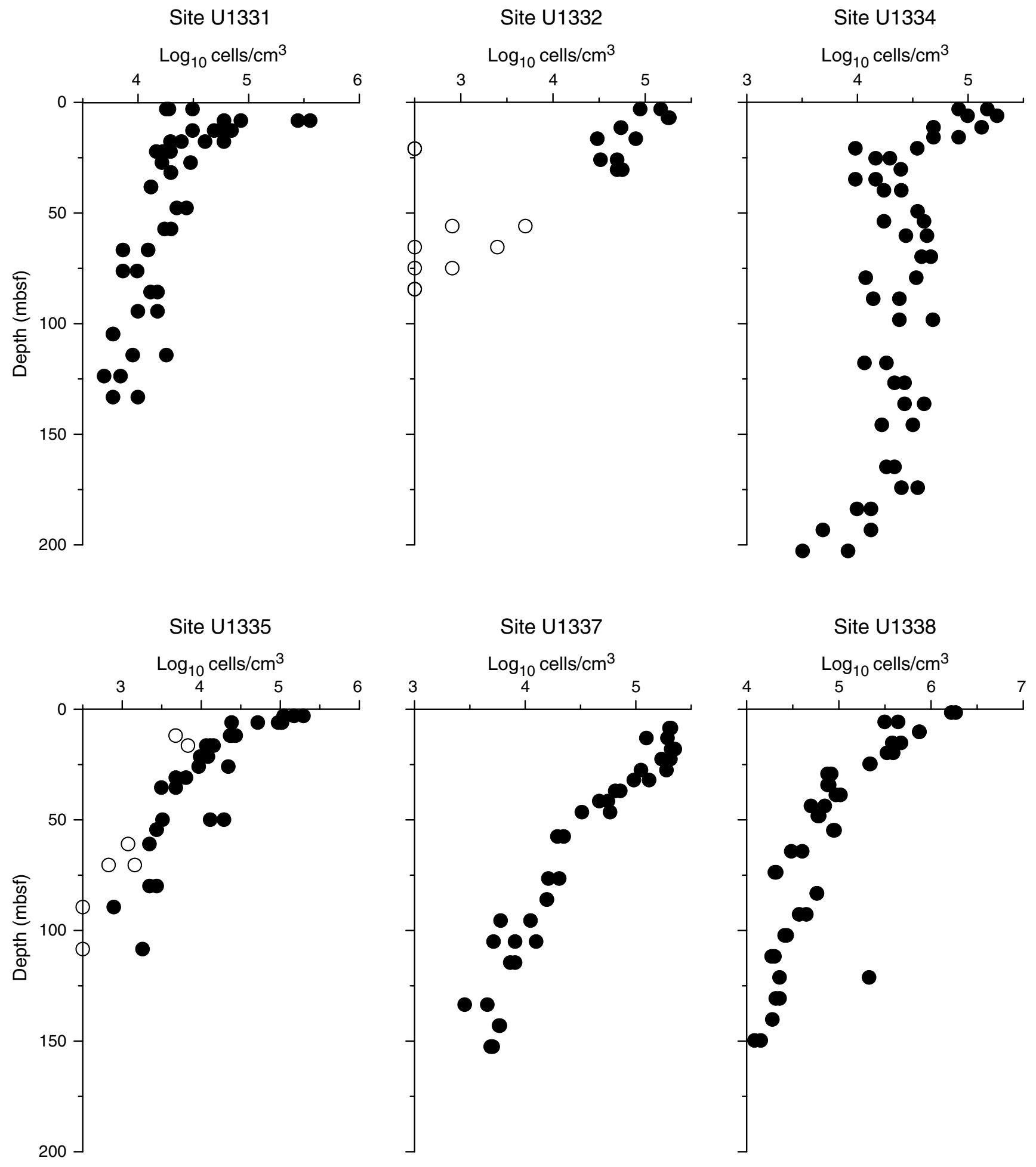
Table T1. Cell counts from all processed samples, Site U1331.

\begin{tabular}{|c|c|c|}
\hline $\begin{array}{l}\text { Core, section, } \\
\text { interval }(\mathrm{cm})\end{array}$ & $\begin{array}{l}\text { Depth } \\
\text { (mbsf) }\end{array}$ & $\begin{array}{l}\text { Above detection } \\
\quad\left(\text { cells } / \mathrm{cm}^{3}\right)\end{array}$ \\
\hline \multicolumn{3}{|l|}{ 320-U1331A- } \\
\hline $1 \mathrm{H}-3,0-3$ & 3.0 & $3.1 \mathrm{E}+04$ \\
\hline $1 \mathrm{H}-3,0-3$ & 3.0 & $1.9 \mathrm{E}+04$ \\
\hline $1 \mathrm{H}-3,0-3$ & 3.0 & $1.8 \mathrm{E}+04$ \\
\hline $2 \mathrm{H}-3,0-3$ & 8.2 & $2.8 \mathrm{E}+05$ \\
\hline $2 \mathrm{H}-3,0-3$ & 8.2 & $3.6 \mathrm{E}+05$ \\
\hline $2 \mathrm{H}-3,0-3$ & 8.2 & $8.5 \mathrm{E}+04$ \\
\hline $2 \mathrm{H}-3,0-3$ & 8.2 & $6.0 \mathrm{E}+04$ \\
\hline $2 \mathrm{H}-6,0-3$ & 12.7 & $3.1 \mathrm{E}+04$ \\
\hline $2 \mathrm{H}-6,0-3$ & 12.7 & $4.9 \mathrm{E}+04$ \\
\hline $2 \mathrm{H}-6,0-3$ & 12.7 & $5.5 \mathrm{E}+04$ \\
\hline $2 \mathrm{H}-6,0-3$ & 12.7 & $7.0 \mathrm{E}+04$ \\
\hline $3 \mathrm{H}-3,0-3$ & 17.7 & $4.0 \mathrm{E}+04$ \\
\hline $3 \mathrm{H}-3,0-3$ & 17.7 & $6.0 \mathrm{E}+04$ \\
\hline $3 \mathrm{H}-3,0-3$ & 17.7 & $2.5 \mathrm{E}+04$ \\
\hline $3 \mathrm{H}-3,0-3$ & 17.7 & $2.0 \mathrm{E}+04$ \\
\hline $3 \mathrm{H}-6,0-3$ & 22.2 & $1.8 \mathrm{E}+04$ \\
\hline $3 \mathrm{H}-6,0-3$ & 22.2 & $1.7 \mathrm{E}+04$ \\
\hline $3 \mathrm{H}-6,0-3$ & 22.2 & $1.5 \mathrm{E}+04$ \\
\hline $3 \mathrm{H}-6,0-3$ & 22.2 & $2.0 \mathrm{E}+04$ \\
\hline $4 \mathrm{H}-3,0-3$ & 27.2 & $1.6 \mathrm{E}+04$ \\
\hline $4 \mathrm{H}-3,0-3$ & 27.2 & $3.0 \mathrm{E}+04$ \\
\hline $4 \mathrm{H}-6,0-3$ & 31.7 & $2.0 \mathrm{E}+04$ \\
\hline $4 \mathrm{H}-6,0-3$ & 31.7 & $2.0 \mathrm{E}+04$ \\
\hline $5 \mathrm{H}-4,0-3$ & 38.2 & $1.3 \mathrm{E}+04$ \\
\hline $5 \mathrm{H}-4,0-3$ & 38.2 & $1.3 \mathrm{E}+04$ \\
\hline $6 \mathrm{H}-4,0-3$ & 47.7 & $2.7 \mathrm{E}+04$ \\
\hline $6 \mathrm{H}-4,0-3$ & 47.7 & $2.2 \mathrm{E}+04$ \\
\hline $7 \mathrm{H}-4,0-3$ & 57.2 & $2.0 \mathrm{E}+04$ \\
\hline $7 \mathrm{H}-4,0-3$ & 57.2 & $1.7 \mathrm{E}+04$ \\
\hline $8 \mathrm{H}-4,0-3$ & 66.7 & $7.3 E+03$ \\
\hline $8 \mathrm{H}-4,0-3$ & 66.7 & $1.2 \mathrm{E}+04$ \\
\hline $9 \mathrm{H}-4,0-3$ & 76.2 & $7.3 \mathrm{E}+03$ \\
\hline $9 \mathrm{H}-4,0-3$ & 76.2 & $9.8 \mathrm{E}+03$ \\
\hline $10 \mathrm{H}-4,0-3$ & 85.7 & $1.3 \mathrm{E}+04$ \\
\hline $10 \mathrm{H}-4,0-3$ & 85.7 & $1.5 \mathrm{E}+04$ \\
\hline $11 \mathrm{H}-4,0-3$ & 94.4 & $10.0 \mathrm{E}+03$ \\
\hline $11 \mathrm{H}-4,0-3$ & 94.4 & $1.5 \mathrm{E}+04$ \\
\hline $12 \mathrm{H}-4,0-3$ & 104.7 & $5.9 \mathrm{E}+03$ \\
\hline $12 \mathrm{H}-4,0-3$ & 104.7 & $5.9 E+03$ \\
\hline $13 \mathrm{H}-4,0-3$ & 114.2 & $9.0 \mathrm{E}+03$ \\
\hline $13 \mathrm{H}-4,0-3$ & 114.2 & $1.8 \mathrm{E}+04$ \\
\hline $14 \mathrm{H}-4,0-3$ & 123.7 & $6.9 \mathrm{E}+03$ \\
\hline $14 \mathrm{H}-4,0-3$ & 123.7 & $4.9 \mathrm{E}+03$ \\
\hline $15 \mathrm{H}-4,0-3$ & 133.2 & $10.0 \mathrm{E}+03$ \\
\hline $15 \mathrm{H}-4,0-3$ & 133.2 & $5.9 \mathrm{E}+03$ \\
\hline
\end{tabular}


Table T2. Cell counts from all processed samples, Site U1332.

\begin{tabular}{|c|c|c|c|}
\hline $\begin{array}{l}\text { Core, section, } \\
\text { interval }(\mathrm{cm})\end{array}$ & $\begin{array}{l}\text { Depth } \\
\text { (mbsf) }\end{array}$ & $\begin{array}{l}\text { Above MDL } \\
\left(\text { cells } / \mathrm{cm}^{3}\right)\end{array}$ & $\begin{array}{l}\text { Below MDL } \\
\left(\text { cells } / \mathrm{cm}^{3}\right)\end{array}$ \\
\hline \multicolumn{4}{|l|}{ 320-U1332A- } \\
\hline $1 \mathrm{H}-3,0-3$ & 3.0 & $8.8 \mathrm{E}+04$ & \\
\hline $1 \mathrm{H}-3,0-3$ & 3.0 & $1.5 \mathrm{E}+05$ & \\
\hline $2 \mathrm{H}-3,0-3$ & 6.9 & $1.8 \mathrm{E}+05$ & \\
\hline $2 \mathrm{H}-3,0-3$ & 6.9 & $1.8 \mathrm{E}+05$ & \\
\hline $2 \mathrm{H}-6,0-3$ & 11.4 & & \\
\hline $2 \mathrm{H}-6,0-3$ & 11.4 & & \\
\hline $3 \mathrm{H}-3,0-3$ & 16.4 & & \\
\hline $3 \mathrm{H}-3,0-3$ & 16.4 & & \\
\hline $3 \mathrm{H}-6,0-3$ & 20.9 & & $5.5 \mathrm{E}+04$ \\
\hline $3 \mathrm{H}-6,0-3$ & 20.9 & & $5.5 \mathrm{E}+04$ \\
\hline $4 \mathrm{H}-3,0-3$ & 25.9 & $5.0 \mathrm{E}+04$ & $3.0 \mathrm{E}+04$ \\
\hline $4 \mathrm{H}-3,0-3$ & 25.9 & $3.3 \mathrm{E}+04$ & $7.9 \mathrm{E}+04$ \\
\hline $4 \mathrm{H}-6,0-3$ & 30.4 & $5.6 \mathrm{E}+04$ & \\
\hline $4 \mathrm{H}-6,0-3$ & 30.4 & $5.0 \mathrm{E}+04$ & \\
\hline $7 \mathrm{H}-4,0-3$ & 55.9 & & $8.1 \mathrm{E}+02$ \\
\hline $7 \mathrm{H}-4,0-3$ & 55.9 & & $5.0 \mathrm{E}+03$ \\
\hline $8 \mathrm{H}-4,0-3$ & 65.4 & & BD \\
\hline $8 \mathrm{H}-4,0-3$ & 65.4 & & $2.5 \mathrm{E}+03$ \\
\hline $9 \mathrm{H}-4,0-3$ & 74.9 & & $8.1 \mathrm{E}+02$ \\
\hline $9 \mathrm{H}-4,0-3$ & 74.9 & & BD \\
\hline $10 \mathrm{H}-4,0-3$ & 84.4 & & $\mathrm{BD}$ \\
\hline $10 \mathrm{H}-4,0-3$ & 84.4 & & BD \\
\hline
\end{tabular}

$\mathrm{MDL}=$ minimum detection limit, $\mathrm{BD}=$ cell counts below the mean blank 
Table T3. Cell counts from all processed samples, Site U1334.

\begin{tabular}{lrr}
\hline $\begin{array}{c}\text { Core, section, } \\
\text { interval (cm) }\end{array}$ & $\begin{array}{r}\text { Depth } \\
\text { (mbsf) }\end{array}$ & $\begin{array}{c}\text { Above MDL } \\
\left(\text { cells } / \mathrm{cm}{ }^{3}\right)\end{array}$ \\
\hline $320-\mathrm{U} 1334 \mathrm{~A}-$ & & \\
$1 \mathrm{H}-3,0-3$ & 3.03 & $8.22 \mathrm{E}+04$ \\
$1 \mathrm{H}-3,0-3$ & 3.03 & $1.49 \mathrm{E}+05$ \\
$1 \mathrm{H}-5,0-3$ & 6.03 & $9.89 \mathrm{E}+04$ \\
$1 \mathrm{H}-5,0-3$ & 6.03 & $1.83 \mathrm{E}+05$ \\
$2 \mathrm{H}-3,0-3$ & 11.23 & $1.32 \mathrm{E}+05$ \\
$2 \mathrm{H}-3,0-3$ & 11.23 & $4.87 \mathrm{E}+04$ \\
$2 \mathrm{H}-6,0-3$ & 15.73 & $4.87 \mathrm{E}+04$ \\
$2 \mathrm{H}-6,0-3$ & 15.73 & $8.22 \mathrm{E}+04$ \\
$3 \mathrm{H}-3,0-3$ & 20.73 & $9.58 \mathrm{E}+03$ \\
$3 \mathrm{H}-3,0-3$ & 20.73 & $3.47 \mathrm{E}+04$ \\
$3 \mathrm{H}-6,0-3$ & 25.23 & $1.46 \mathrm{E}+04$ \\
$3 \mathrm{H}-6,0-3$ & 25.23 & $1.96 \mathrm{E}+04$ \\
$4 \mathrm{H}-3,0-3$ & 30.23 & $2.47 \mathrm{E}+04$ \\
$4 \mathrm{H}-6,0-3$ & 34.73 & $9.58 \mathrm{E}+03$ \\
$4 \mathrm{H}-6,0-3$ & 34.73 & $1.46 \mathrm{E}+04$ \\
$5 \mathrm{H}-3,0-3$ & 39.73 & $2.49 \mathrm{E}+04$ \\
$5 \mathrm{H}-3,0-3$ & 39.73 & $1.74 \mathrm{E}+04$ \\
$6 \mathrm{H}-3,0-3$ & 49.23 & $3.49 \mathrm{E}+04$ \\
$6 \mathrm{H}-6,0-3$ & 53.73 & $4.00 \mathrm{E}+04$ \\
$6 \mathrm{H}-6,0-3$ & 53.73 & $1.74 \mathrm{E}+04$ \\
$7 \mathrm{H}-4,0-3$ & 60.23 & $4.25 \mathrm{E}+04$ \\
$7 \mathrm{H}-4,0-3$ & 60.23 & $2.74 \mathrm{E}+04$ \\
$8 \mathrm{H}-4,0-3$ & 69.73 & $3.80 \mathrm{E}+04$ \\
$8 \mathrm{H}-4,0-3$ & 69.73 & $4.61 \mathrm{E}+04$ \\
$9 \mathrm{H}-4,0-3$ & 79.23 & $1.19 \mathrm{E}+04$ \\
$9 \mathrm{H}-4,0-3$ & 79.23 & $3.40 \mathrm{E}+04$ \\
$10 \mathrm{H}-4,0-3$ & 88.73 & $1.39 \mathrm{E}+04$ \\
$10 \mathrm{H}-4,0-3$ & 88.73 & $2.39 \mathrm{E}+04$ \\
$11 \mathrm{H}-4,0-3$ & 98.23 & $4.81 \mathrm{E}+04$ \\
$11 \mathrm{H}-4,0-3$ & 98.23 & $2.39 \mathrm{E}+04$ \\
$13 \mathrm{H}-5,0-3$ & 117.73 & $1.16 \mathrm{E}+04$ \\
$13 \mathrm{H}-5,0-3$ & 117.73 & $1.83 \mathrm{E}+04$ \\
$14 \mathrm{H}-4,0-3$ & 126.73 & $2.66 \mathrm{E}+04$ \\
$14 \mathrm{H}-4,0-3$ & 126.73 & $2.16 \mathrm{E}+04$ \\
$15 \mathrm{H}-4,0-3$ & 136.23 & $4.01 \mathrm{E}+04$ \\
$15 \mathrm{H}-4,0-3$ & 136.23 & $2.66 \mathrm{E}+04$ \\
$16 \mathrm{H}-4,0-3$ & 145.73 & $3.17 \mathrm{E}+04$ \\
$16 \mathrm{H}-4,0-3$ & 145.73 & $1.66 \mathrm{E}+04$ \\
$18 \mathrm{H}-4,0-3$ & 164.73 & $1.83 \mathrm{E}+04$ \\
$18 \mathrm{H}-4,0-3$ & 164.73 & $2.16 \mathrm{E}+04$ \\
$19 \mathrm{H}-4,0-3$ & 174.15 & $3.50 \mathrm{E}+04$ \\
$19 \mathrm{H}-4,0-3$ & 174.15 & $2.50 \mathrm{E}+04$ \\
$20 \mathrm{H}-4,0-3$ & 183.73 & $1.32 \mathrm{E}+04$ \\
$20 \mathrm{H}-4,0-3$ & 183.73 & $9.89 \mathrm{E}+03$ \\
$21 \mathrm{H}-4,0-3$ & 193.23 & $1.32 \mathrm{E}+04$ \\
$21 \mathrm{H}-4,0-3$ & 193.23 & $4.87 \mathrm{E}+03$ \\
& 202.73 & $3.19 \mathrm{E}+03$ \\
& 202.73 & $8.22 \mathrm{E}+03$ \\
\hline
\end{tabular}

$\mathrm{MDL}=$ minimum detection limit. 
Table T4. Cell counts from all processed samples, Site U1335.

\begin{tabular}{|c|c|c|c|}
\hline $\begin{array}{l}\text { Core, section, } \\
\text { interval }(\mathrm{cm})\end{array}$ & $\begin{array}{l}\text { Depth } \\
\text { (mbsf) }\end{array}$ & $\begin{array}{l}\text { Above MDL } \\
\left(\text { cells } / \mathrm{cm}^{3}\right)\end{array}$ & $\begin{array}{l}\text { Below MDL } \\
\left(\text { cells } / \mathrm{cm}^{3}\right)\end{array}$ \\
\hline \multicolumn{4}{|l|}{ 320-U1335A- } \\
\hline $1 \mathrm{H}-3,0-3$ & 3.0 & $2.0 \mathrm{E}+05$ & \\
\hline $1 \mathrm{H}-3,0-3$ & 3.0 & $1.5 \mathrm{E}+05$ & \\
\hline $1 \mathrm{H}-3,0-3$ & 3.0 & $1.1 \mathrm{E}+05$ & \\
\hline $1 \mathrm{H}-5,0-3$ & 6.0 & $9.4 \mathrm{E}+04$ & \\
\hline $1 \mathrm{H}-5,0-3$ & 6.0 & $2.4 \mathrm{E}+04$ & \\
\hline $1 \mathrm{H}-5,0-3$ & 6.0 & $5.2 \mathrm{E}+04$ & \\
\hline $1 \mathrm{H}-5,0-3$ & 6.0 & $1.1 \mathrm{E}+05$ & \\
\hline $1 \mathrm{H}-5,0-3$ & 6.0 & $1.0 \mathrm{E}+05$ & \\
\hline $2 \mathrm{H}-3,0-3$ & 11.9 & & $4.7 \mathrm{E}+03$ \\
\hline $2 \mathrm{H}-3,0-3$ & 11.9 & $2.4 \mathrm{E}+04$ & \\
\hline $2 \mathrm{H}-3,0-3$ & 11.9 & $2.7 \mathrm{E}+04$ & \\
\hline $2 \mathrm{H}-3,0-3$ & 11.9 & $2.3 \mathrm{E}+04$ & \\
\hline $2 \mathrm{H}-6,0-3$ & 16.4 & $1.4 \mathrm{E}+04$ & \\
\hline $2 \mathrm{H}-6,0-3$ & 16.4 & $1.2 \mathrm{E}+04$ & \\
\hline $2 \mathrm{H}-6,0-3$ & 16.4 & & $6.8 \mathrm{E}+03$ \\
\hline $2 \mathrm{H}-6,0-3$ & 16.4 & $1.3 \mathrm{E}+04$ & \\
\hline $3 \mathrm{H}-3,0-3$ & 21.4 & $9.7 \mathrm{E}+03$ & \\
\hline $3 \mathrm{H}-3,0-3$ & 21.4 & $1.2 \mathrm{E}+04$ & \\
\hline $3 \mathrm{H}-6,0-3$ & 25.9 & $2.2 \mathrm{E}+04$ & \\
\hline $3 \mathrm{H}-6,0-3$ & 25.9 & $9.3 \mathrm{E}+03$ & \\
\hline $4 \mathrm{H}-3,0-3$ & 30.9 & $4.8 \mathrm{E}+03$ & \\
\hline $4 \mathrm{H}-3,0-3$ & 30.9 & $6.4 \mathrm{E}+03$ & \\
\hline $4 \mathrm{H}-6,0-3$ & 35.4 & $4.8 \mathrm{E}+03$ & \\
\hline $4 \mathrm{H}-6,0-3$ & 35.4 & $3.1 \mathrm{E}+03$ & \\
\hline $6 \mathrm{H}-3,0-3$ & 49.9 & $1.9 \mathrm{E}+04$ & \\
\hline $6 \mathrm{H}-3,0-3$ & 49.9 & $1.3 \mathrm{E}+04$ & \\
\hline $6 \mathrm{H}-3,0-3$ & 49.9 & $3.2 \mathrm{E}+03$ & \\
\hline $6 \mathrm{H}-6,0-3$ & 54.4 & $2.7 \mathrm{E}+03$ & \\
\hline $6 \mathrm{H}-6,0-3$ & 54.4 & $2.7 \mathrm{E}+03$ & \\
\hline $7 \mathrm{H}-4,0-3$ & 60.9 & & $1.2 \mathrm{E}+03$ \\
\hline $7 \mathrm{H}-4,0-3$ & 60.9 & $2.2 \mathrm{E}+03$ & \\
\hline $8 \mathrm{H}-4,0-3$ & 70.4 & & $1.4 \mathrm{E}+03$ \\
\hline $8 \mathrm{H}-4,0-3$ & 70.4 & & $6.7 \mathrm{E}+02$ \\
\hline $9 \mathrm{H}-4,0-3$ & 79.9 & $2.7 \mathrm{E}+03$ & \\
\hline $9 \mathrm{H}-4,0-3$ & 79.9 & $2.2 \mathrm{E}+03$ & \\
\hline $10 \mathrm{H}-4,0-3$ & 89.4 & $7.8 \mathrm{E}+02$ & \\
\hline $10 \mathrm{H}-4,0-3$ & 89.4 & & BD \\
\hline $11 \mathrm{H}-3,0-3$ & 97.4 & & \\
\hline $11 \mathrm{H}-3,0-3$ & 97.4 & & \\
\hline $12 \mathrm{H}-4,0-3$ & 108.4 & $1.8 \mathrm{E}+03$ & \\
\hline $12 \mathrm{H}-4,0-3$ & 108.4 & & $B D$ \\
\hline
\end{tabular}

$\mathrm{MDL}=$ minimum detection limit, $\mathrm{BD}=$ cell counts below the mean blank 
Table T5. Cell counts from all processed samples, Site U1337.

\begin{tabular}{crr}
\hline $\begin{array}{c}\text { Core, section, } \\
\text { interval (cm) }\end{array}$ & $\begin{array}{r}\text { Depth } \\
\text { (mbsf) }\end{array}$ & $\begin{array}{c}\text { Above MDL } \\
\left.\text { (cells } / \mathrm{cm}^{3}\right)\end{array}$ \\
\hline $321-\mathrm{U} 1337 \mathrm{~A}-$ & & \\
$2 \mathrm{H}-3,0-3$ & 8.5 & $2.1 \mathrm{E}+05$ \\
$2 \mathrm{H}-3,0-3$ & 8.5 & $2.0 \mathrm{E}+05$ \\
$2 \mathrm{H}-6,0-3$ & 13.0 & $1.2 \mathrm{E}+04$ \\
$2 \mathrm{H}-6,0-3$ & 13.0 & $2.7 \mathrm{E}+04$ \\
$2 \mathrm{H}-6,0-3$ & 13.0 & $1.2 \mathrm{E}+05$ \\
$2 \mathrm{H}-6,0-3$ & 13.0 & $1.9 \mathrm{E}+05$ \\
$3 \mathrm{H}-3,0-3$ & 18.0 & $2.1 \mathrm{E}+05$ \\
$3 \mathrm{H}-3,0-3$ & 18.0 & $2.2 \mathrm{E}+05$ \\
$3 \mathrm{H}-6,0-3$ & 22.5 & $1.7 \mathrm{E}+05$ \\
$3 \mathrm{H}-6,0-3$ & 22.5 & $2.1 \mathrm{E}+05$ \\
$4 \mathrm{H}-3,0-3$ & 27.5 & $1.9 \mathrm{E}+05$ \\
$4 \mathrm{H}-3,0-3$ & 27.5 & $1.1 \mathrm{E}+05$ \\
$4 \mathrm{H}-6,0-3$ & 32.0 & $1.3 \mathrm{E}+05$ \\
$4 \mathrm{H}-6,0-3$ & 32.0 & $9.6 \mathrm{E}+04$ \\
$5 \mathrm{H}-2,0-3$ & 36.9 & $6.5 \mathrm{E}+04$ \\
$5 \mathrm{H}-2,0-3$ & 36.9 & $7.2 \mathrm{E}+04$ \\
$5 \mathrm{H}-6,0-3$ & 41.5 & $5.6 \mathrm{E}+04$ \\
$5 \mathrm{H}-6,0-3$ & 41.5 & $4.7 \mathrm{E}+04$ \\
$6 \mathrm{H}-3,0-3$ & 46.5 & $5.8 \mathrm{E}+04$ \\
$6 \mathrm{H}-3,0-3$ & 46.5 & $3.3 \mathrm{E}+04$ \\
$6 \mathrm{H}-6,0-3$ & 51.0 & $10.0 \mathrm{E}+03$ \\
$6 \mathrm{H}-6,0-3$ & 51.0 & $9.3 \mathrm{E}+03$ \\
$7 \mathrm{H}-4,0-3$ & 57.5 & $2.0 \mathrm{E}+04$ \\
$7 \mathrm{H}-4,0-3$ & 57.5 & $2.2 \mathrm{E}+04$ \\
$9 \mathrm{H}-4,0-3$ & 76.5 & $1.6 \mathrm{E}+04$ \\
$9 \mathrm{H}-4,0-3$ & 76.5 & $2.0 \mathrm{E}+04$ \\
$10 \mathrm{H}-4,0-3$ & 86.0 & $1.6 \mathrm{E}+04$ \\
$10 \mathrm{H}-4,0-3$ & 86.0 & $1.6 \mathrm{E}+04$ \\
$11 \mathrm{H}-4,0-3$ & 95.5 & $6.0 \mathrm{E}+03$ \\
$11 \mathrm{H}-4,0-3$ & 95.5 & $1.1 \mathrm{E}+04$ \\
$12 \mathrm{H}-4,0-3$ & 105.0 & $1.3 \mathrm{E}+04$ \\
$12 \mathrm{H}-4,0-3$ & 105.0 & $5.2 \mathrm{E}+03$ \\
$12 \mathrm{H}-4,0-3$ & 105.0 & $8.1 \mathrm{E}+03$ \\
$13 \mathrm{H}-4,0-3$ & 114.5 & $7.3 \mathrm{E}+03$ \\
$13 \mathrm{H}-4,0-3$ & 114.5 & $8.1 \mathrm{E}+03$ \\
$15 \mathrm{H}-4,0-3$ & 133.5 & $2.8 \mathrm{E}+03$ \\
$15 \mathrm{H}-4,0-3$ & 133.5 & $4.5 \mathrm{E}+03$ \\
$16 \mathrm{H}-4,0-3$ & 143.0 & $5.9 \mathrm{E}+03$ \\
$16 \mathrm{H}-4,0-3$ & 143.0 & $5.8 \mathrm{E}+03$ \\
$17 \mathrm{H}-4,0-3$ & 152.5 & $4.9 \mathrm{E}+03$ \\
$17 \mathrm{H}-4,0-3$ & 152.5 & $5.1 \mathrm{E}+03$ \\
\hline & & \\
\hline & &
\end{tabular}

$\mathrm{MDL}=$ minimum detection limit. 
Table T6. Cell counts from all processed samples, Site U1338.

\begin{tabular}{crc}
\hline $\begin{array}{c}\text { Core, section, } \\
\text { interval (cm) }\end{array}$ & $\begin{array}{c}\text { Depth } \\
\text { (mbsf) }\end{array}$ & $\begin{array}{c}\text { Above MDL } \\
\text { (cells/cm } / \mathrm{cm}^{3}\end{array}$ \\
\hline $321-\mathrm{U} 1338 \mathrm{~A}-$ & & \\
1H-2, 0-3 & 1.5 & $1.8 \mathrm{E}+06$ \\
$1 \mathrm{H}-2,0-3$ & 1.5 & $1.7 \mathrm{E}+06$ \\
$2 \mathrm{H}-3,0-3$ & 5.7 & $4.4 \mathrm{E}+05$ \\
$2 \mathrm{H}-3,0-3$ & 5.7 & $3.1 \mathrm{E}+05$ \\
$2 \mathrm{H}-6,0-3$ & 10.2 & $7.5 \mathrm{E}+05$ \\
$2 \mathrm{H}-6,0-3$ & 10.2 & $7.4 \mathrm{E}+05$ \\
$3 \mathrm{H}-3,0-3$ & 15.2 & $4.7 \mathrm{E}+05$ \\
$3 \mathrm{H}-3,0-3$ & 15.2 & $3.8 \mathrm{E}+05$ \\
$3 \mathrm{H}-6,0-3$ & 19.7 & $3.9 \mathrm{E}+05$ \\
$3 \mathrm{H}-6,0-3$ & 19.7 & $3.3 \mathrm{E}+05$ \\
$4 \mathrm{H}-3,0-3$ & 24.7 & $2.2 \mathrm{E}+05$ \\
$4 \mathrm{H}-3,0-3$ & 24.7 & $2.2 \mathrm{E}+05$ \\
$4 \mathrm{H}-6,0-3$ & 29.2 & $8.3 \mathrm{E}+04$ \\
$4 \mathrm{H}-6,0-3$ & 29.2 & $7.5 \mathrm{E}+04$ \\
$5 \mathrm{H}-3,0-3$ & 34.2 & $7.8 \mathrm{E}+04$ \\
$5 \mathrm{H}-3,0-3$ & 34.2 & $7.5 \mathrm{E}+04$ \\
$5 \mathrm{H}-6,0-3$ & 38.7 & $1.0 \mathrm{E}+05$ \\
$5 \mathrm{H}-6,0-3$ & 38.7 & $9.3 \mathrm{E}+04$ \\
$6 \mathrm{H}-3,0-3$ & 43.7 & $7.0 \mathrm{E}+04$ \\
$6 \mathrm{H}-3,0-3$ & 43.7 & $5.0 \mathrm{E}+04$ \\
$6 \mathrm{H}-6,0-3$ & 48.2 & $5.9 \mathrm{E}+04$ \\
$6 \mathrm{H}-6,0-3$ & 48.2 & $6.1 \mathrm{E}+04$ \\
$7 \mathrm{H}-4,0-3$ & 54.7 & $8.7 \mathrm{E}+04$ \\
$7 \mathrm{H}-4,0-3$ & 54.7 & $9.0 \mathrm{E}+04$ \\
$8 \mathrm{H}-4,0-3$ & 64.2 & $3.0 \mathrm{E}+04$ \\
$8 \mathrm{H}-4,0-3$ & 64.2 & $4.0 \mathrm{E}+04$ \\
$9 \mathrm{H}-4,0-3$ & 73.7 & $2.0 \mathrm{E}+04$ \\
$9 \mathrm{H}-4,0-3$ & 73.7 & $2.1 \mathrm{E}+04$ \\
$11 \mathrm{H}-4,0-3$ & 92.7 & $4.4 \mathrm{E}+04$ \\
\hline & &
\end{tabular}

$\mathrm{MDL}=$ minimum detection limit. 